\title{
everyday architecture in China
} the ordinary and the anonymous questioning the political
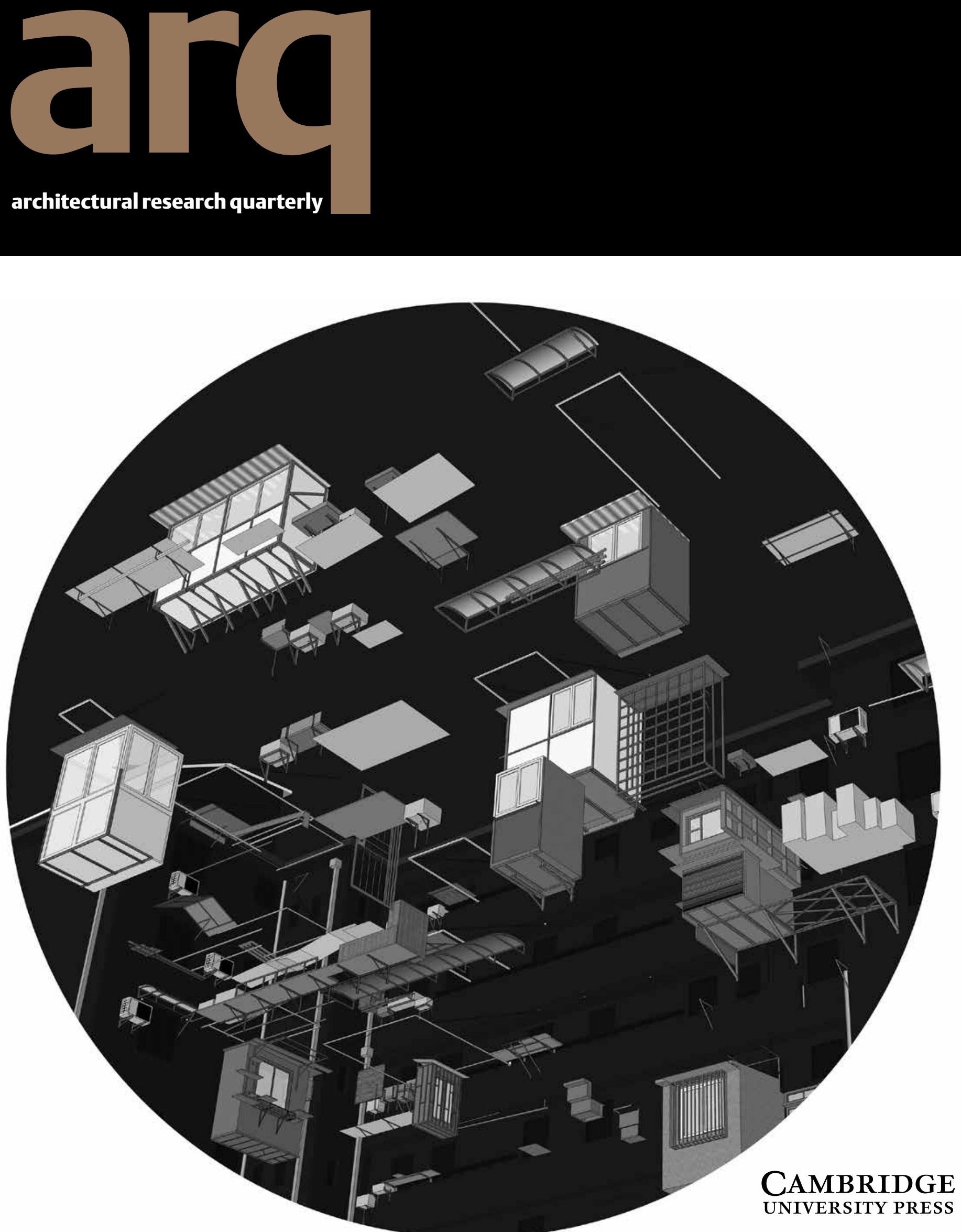
Editor-in-Chief Adam Sharr

E. adam.sharr@ncl.ac.uk

Editor-at-Large Richard Weston

E. richard@richardwestonstudio.com

Editors Samuel Austin

E. samuel.austin@ncl.ac.uk

Martyn Dade-Robertson

E. martyn.dade-robertson@ncl.ac.uk

Graham Farmer

E. graham.farmer@ncl.ac.uk

Zeynep Kezer

E. zeynep.kezer@ncl.ac.uk

Stephen Kite

E. kites@cardiff.ac.uk

Katie Lloyd Thomas

E. katie.lloyd-thomas@ncl.ac.uk

Juliet Odgers

E. juliet.odgers@ncl.ac.uk

Stephen Parnell

E. stephen.parnell@ncl.ac.uk

Editor Edward Wainwright

Reviews + Insight $\quad$ E. edward.wainwright@ncl.ac.uk

\section{Assistant Editor Ruth Lang}

Reviews+Insight $\quad$ E. r.lang2@ncl.ac.uk

Editorial Assistant $\quad$ Ashley Mason

E. arq@ncl.ac.uk

Art Editor+Design Angela Ashton

E. design@angelaashton.co.uk

Editorial Board Simon Allford Allford Hall Monaghan Morris, UK Andrew Ballantyne Newcastle University, UK

Mark Burry The University of Melbourne, Australia

Carlos Eduardo Comas Universidade Federal do Rio Grande do Sul, Brazil

Richard Coyne The University of Edinburgh, UK

Peggy Deamer Yale University, USA

Susannah Hagan University of Westminster, UK

Francine Houben Mecannoo, Holland

Susanne Hofmann Die Baupiloten, TU Berlin, Germany

Louisa Hutton Sauerbruch Hutton, Germany

Mari Hvattum The Oslo School of Architecture and Design, Norway

Timothy W. Hyde MIT, USA

Momoyo Kaijima Atelier Bow-Wow, Japan

Silke Kapp Universidade Federal de Minas Gerais, Brazil

Ulrika Karlsson КтН, Sweden

David Leatherbarrow University of Pennsylvania, USA

Lesley Lokko University of Johannesburg, South Africa

Mary McLeod University of Columbia, USA

Steven A. Moore The University of Texas at Austin, USA

Michael Ostwald The University of Newcastle, Australia

Simo Paavilinen Aalto University, Finland

Jane Rendell Bartlett School of Architecture, UCL, UK

Daniel Rosbottom tu Delft, Holland

Andreas Rumpfhuber Expanded Design, Austria

Simon Sadler University of California, Davis, USA

Flora Samuel University of Reading, uK

Jonathan Sergison Sergison Bates Architects, UK

Despina Stratigakos University at Buffalo, USA

Koen Steemers University of Cambridge, UK

John Tuomey O'Donnell + Tuomey, Ireland

Sarah Wigglesworth Sarah Wigglesworth Architects, UK

Jianfei Zhu The University of Melbourne, Australia

arq: Architectural Research Quarterly (issn 1359-1355) is published four times a year in March, June, September and December. Four parts form a volume. The subscription price which includes print and electronic access (but excluding vat) of volume 21 is $£_{312.00}$ (US $\$ 524.00$ in USA, Canada and Mexico) for institutions; $£_{53.00}$ (US $\$ 81.00$ in USA, Canada and Mexico) for individuals and $E_{3} 8.00$ (US $\$ 63.00$ in USA, Canada and Mexico) for students, which includes print only, ordering direct from the publishers and certifying that the journal is for their personal use. Single parts are $£ 78$.oo net (US \$125.00 in USA, Canada and Mexico) plus postage. EU subscribers (outside the UK) who are not registered for vat should add vat at their country's rate. vat registered members should provide their vat registration number. Japanese prices for institutions (including ASP delivery) are available from Kinokuniya Company Ltd, P.O. Box 55, Chitose, Tokyo 156, Japan. Orders which must be accompanied by payment, may be sent to a bookseller, subscription agent or direct to the publisher: Cambridge University Press, Journals Fulfillment Department, UPH,

Shaftesbury Road, Cambridge CB2 8BS, UK; or in the USA, Canada and Mexico: Cambridge University Press, Journals Fulfillment Department, 1 Liberty Plaza, Floor 20, New York, NY 10006, USA. Copies of the journal for subscribers in the USA, Canada and Mexico are sent by air to New York to arrive with minimum delay.

\section{Copying}

The journal is registered with the Copyright Clearance Center, 222 Rosewood Drive, Danvers, MA 01923, USA. Organizations in the USA who are also registered with C.C.C may therefore copy material (beyond the limits permitted by sections 107 and 108 of U.S. Copyright law) subject to payment to C.C.C. of the per-copy fee of $\$ 16$. This consent does not extend to multiple copying for promotional or commercial purposes. Code 1359-1355/2017/\$16.

ISI Tear Sheet Service, 3501 Market Street, Philadelphia, PA 19104, USA, is authorized to supply single copies of separate articles for private use only.

Organizations authorized by the Copyright Licensing Agency may also copy material subject to the usual conditions.

For all other use, permission should be sought from Cambridge or from the American Branch of Cambridge University Press.

Information on arq: Architectural Research Quarterly and all other Cambridge journals can be accessed via http://www.journals.cambridge.org/

This journal issue has been printed on FSC-certified paper and cover board. FSC is an independent, non-governmental, not-for-profit organization established to promote the responsible management of the world's forests. Please see www.fsc.org for information.

(c) Cambridge University Press 2018

Printed in the UK by Bell \& Bain Ltd, Glasgow 
COVER

Different elements

added to residential

facade.

Seepp. 222-233.

\begin{abstract}
leader
199

Everyday architecture in China

perspective

200

report

203

design

criticism

theory

Why the everyday in China, today? Jianfei Zhu

The Japanese House Luke Tozer

Designing the everyday Wang Hui showcases four case study projects from URBANUS developed as a bottom-up, everyday architecture, and as a challenge to top-down, noneveryday practices.

Learning from the everyday world Shen Zhuang and Xiahong Hua, of Shanghai-based Atelier Archmixing, demonstrate how learning from the everyday world is largely practiceoriented, a way to understand the ever-changing conditions of the built environment and to explore new design strategies.

The everyday: A degree zero agenda for contemporary Chinese architecture Junyang Wang presents three case studies examining the theory, practice and pedagogy of everyday architecture in China, illustrating its social potentials and its practical, poetic and critical operations.

The spatial engenderment of everyday reading: teaching practice in the Chinese village of Shi-shan-xia, Lishui town Yuan Zhu (with Zhuo Chen and Xiwen Liu) shows the instructive meaning of everyday space in teaching practice in a Chinese village, through the introduction of everyday observation, systemic objects, place association and object images.
\end{abstract}

insight

5 Reconstructing the 'everyday' for a political aesthetic in design Jianfei Zhu employs Jacques Rancière's ideas of the 'sensible' and 'aesthetic revolution' to refashion the concept of the 'everyday' for a new departure in design.

Spaces of the Political Michael Dutton reveals how Liu Wencai's Manor House Museum, China, and the Crystal Palace, UK, exemplify two ways in which the everyday can be transformed by distinctive ideas of the political.

\section{Architecture and Ritual by Peter Blundell Jones} Reviewed by Xiang Ren

China's Urban Revolution: Understanding Chinese Eco-Cities by Austin Williams Reviewed by Andrew Law

Encounters with Labour: migrant workers, architects, and building sites in China William Thomson

...Beijing Tom Coward

A subscription form, which may be copied, can be found on page 198 of this issue 